Bartłomiej Gadecki

gadek82@poczta.onet.pl

Prokurator Rejonowy

Olsztyn-Północ w Olsztynie

ul. Iwaszkiewicza $6 / 18$

10-089 Olsztyn

\title{
Nowe przestępstwa w systemie karnoprawnej ochrony dziedzictwa kultury w związku z wejściem w życie ustawy z dnia 25 maja 2017 r. o restytucji narodowych dóbr kultury
}

\author{
New crimes in the criminal law system regarding \\ the protection of cultural heritage in the light \\ of the coming into force on 25 May 2017 \\ the Restitution of National Cultural Property Act
}

Summary: On 25 May 2017, the Act on the Restitution of National Cultural Property was passed. Article 52 of this Act provides a definition of the crime of obstructing proceedings for the return of foreign national cultural property. The Restitution of National Cultural Property Act also introduced changes to the Act on Museums of 21 November 1996 and the Act on Libraries of 27 June 1997 concerning provisions on criminal liability for illegal export (of museum collections and library materials respectively). The author discusses the new crimes included in these three Acts, and concludes that different ways of determining the amount of exemplary damages are contained in the provisions concerning illegal export included in the Act on Museums, the Act on Libraries and the Act on the Protection and Guardianship of Monuments. It seems necessary to impose stricter sanctions for the crime of illegal export of archives in the Act on the National Archival Resource and State Archives of 


\section{ARTYKUEY}

Bartłomiej Gadecki

14 July 1983. In conclusion it is noted that the new regulations have undoubtedly strengthened the protection of cultural heritage under the criminal law system.

Keywords: Criminal Code, the Act on the Protection and Guardianship of Monuments, the Act on the Restitution of National Cultural Property, the Act on Libraries, the Act on Museums

Streszczenie: W dniu 25 maja 2017 r. została uchwalona ustawa o restytucji narodowych dóbr kultury. W art. 52 tej ustawy uregulowano przestępstwo utrudniania postępowania o zwrot zagranicznego narodowego dobra kultury. Jednocześnie ustawa o restytucji narodowych dóbr kultury dokonała zmian kilku ustaw, wprowadzając w ustawie $z$ dnia 21 listopada 1996 r. o muzeach oraz w ustawie z dnia 27 czerwca 1997 r. o bibliotekach przepisy dotyczące odpowiedzialności karnej za nielegalny wywóz za granicę (odpowiednio muzealium i materiału bibliotecznego). Autor omawia nowe przepisy karne zawarte w ustawie o restytucji narodowych dóbr kultury, w ustawie o muzeach oraz w ustawie o bibliotekach. W artykule dostrzeżono, że istnieje różny sposób określenia wysokości nawiązki w przepisach dotyczących nielegalnego wywozu zawartych w ustawie o muzeach, $w$ ustawie o bibliotekach oraz $w$ ustawie o ochronie zabytków i opiece nad zabytkami. Należy przyjąć, że kwota minimalnego wynagrodzenia potrzebna do ustalania wysokości nawiązki jest ustalana na podstawie art. 2 ustawy o minimalnym wynagrodzeniu za pracę. Dostrzeżono, że konieczne jest podwyższenie sankcji za przestępstwo nielegalnego wywozu materiałów archiwalnych, uregulowane w ustawie $z$ dnia 14 lipca 1983 r. o narodowym zasobie archiwalnym i archiwach. Zauważono, że wprowadzenie nowych przestępstw niewątpliwie wzmocniło system karnoprawnej ochrony dziedzictwa kultury.

Słowa kluczowe: Kodeks karny, nawiązka, ustawa o ochronie zabytków i opiece nad zabytkami, ustawa o restytucji narodowych dóbr kultury, ustawa o bibliotekach, ustawa o muzeach 
Nowe przestępstwa w systemie karnoprawnej ochrony dziedzictwa kultury...

New crimes in the criminal law system regarding the protection of cultural heritage...

\section{Wprowadzenie}

Karnoprawna ochrona dziedzictwa kultury jest jednym z elementów ochrony dziedzictwa kultury ${ }^{1}$. Nie ogranicza się ona jednak tylko do ochrony zabytków. Przykładowo można wskazać, że Wojciech Radecki do pozakodeksowych przestępstw w dziedzinie kultury zaliczył przestępstwa z ustawy z dnia 23 lipca 2003 r. o ochronie zabytków i opiece nad zabytkami² (dalej: ustawa o ochronie zabytków lub u.o.z.) oraz ustawy z dnia 14 lipca 1983 r. o narodowym zasobie archiwalnym i $\operatorname{archiwach}^{3}$ (dalej: u.n.z.a.) ${ }^{4}$.

W dniu 25 maja 2017 r. została uchwalona ustawa o restytucji narodowych dóbr kultury ${ }^{5}$ (dalej: ustawa o restytucji lub u.r.). W ustawie tej zawarto przepis karny związany z jej zakresem oraz dokonano zmian innych ustaw poświęconych ochronie szeroko rozumianego dziedzictwa kultury, wprowadzając do niektórych z nich nowe przepisy regulujące odpowiedzialność karną.

Celem niniejszego artykułu jest omówienie nowych przestępstw w systemie karnoprawnej ochrony dziedzictwa kultury w związku z wejściem w życie ustawy o restytucji. Na marginesie należy zaznaczyć, że wspomniana ustawa wprowadziła również do ustawy o ochronie zabytków nowe wykroczenie (art. 119a6).

\section{Przestępstwo z ustawy o restytucji}

W ustawie o restytucji, w rozdziale 6 zatytułowanym „Przepisy karne” zawarto dwa przepisy. Umieszczony $w$ tym rozdziale art. 52 reguluje przestępstwo utrudniania postępowania o zwrot i brzmi:

1. Kto utrudnia postępowanie o zwrot zagranicznego narodowego dobra kultury, o którym mowa w art. 18 ust. 1, w ten sposób, że w celu ukrycia tego dobra udziela właściwemu organowi nieprawdziwych informacji lub zataja przed tym organem informację o miejscu przechowywania tego dobra, podlega karze pozbawienia wolności od 3 miesięcy do lat 5.

2. W wypadku mniejszej wagi sprawca podlega grzywnie, karze ograniczenia wolności albo pozbawienia wolności do roku.

\footnotetext{
1 Szerzej na temat systemu ochrony dziedzictwa kultury zob. K. Zeidler, Prawo ochrony dziedzictwa kultury, Wolters Kluwer Polska, Warszawa 2007, s. 286-290.

2 Ustawa z dnia 23 lipca 2003 r. o ochronie zabytków i opiece nad zabytkami, tekst jedn. Dz. U. z 2014 r., poz. 1446 ze zm.

3 Ustawa z dnia 14 lipca 1983 r. o narodowym zasobie archiwalnym i archiwach, tekst jedn. Dz. U.z 2016 r., poz. 1506 ze zm.

4 W. Radecki, w: System prawa karnego, t. 11: M. Bojarski (red.), Szczególne dziedziny prawa karnego. Prawo karne wojskowe, skarbowe i pozakodeksowe, C.H. Beck, Instytut Nauk Prawnych PAN, Warszawa 2014, s. 1007-1032.

5 Ustawa z dnia 25 maja 2017 r. o restytucji narodowych dóbr kultury, Dz. U. poz. 1086.

6 „Kto wbrew ciążącemu na nim obowiązkowi nie prowadzi księgi ewidencyjnej albo prowadzi ją w sposób nierzetelny lub niezgodny z prawdą, podlega karze grzywny".
} 


\section{ARTYKUŁY}

Bartłomiej Gadecki

3. W razie skazania za przestępstwo określone w ust. 1 sąd może orzec nawiązkę na wskazany cel społeczny związany z opieką nad zabytkami.

Wprowadzenie przepisu penalizującego utrudnianie postępowania o zwrot dobra kultury postulowano w doktrynie?.

Z kolei art. 53 u.r. reguluje szczególną postać czynnego żalu, wskazując, że:

Nie podlega karze za przestępstwo określone w art. 52, kto dobrowolnie zwrócił dobro kultury właściwym organom państwa, z którego zostało wyprowadzone, lub właściwym organom polskim lub kto ujawnił wobec właściwego organu miejsce przechowywania dobra kultury lub osobę je przechowującą, na skutek czego dobro kultury zostało odnalezione.

Omawiając wyżej wymienione przepisy, trzeba zaznaczyć, że w ustawie o restytucji objaśniono kilka istotnych pojęć. Zdefiniowano pojęcie „dobro kultury” jako „zabytek w rozumieniu art. 3 pkt 1 ustawy z dnia 23 lipca 2003 r. o ochronie zabytków i opiece nad zabytkami (Dz. U. z 2014 r. poz. 1446, z późn. zm.), rzecz ruchomą niebędącą zabytkiem, a także ich części składowe lub zespoły, których zachowanie leży w interesie społecznym ze względu na ich wartość artystyczną, historyczną lub naukową, lub ze względu na ich znaczenie dla dziedzictwa i rozwoju kulturalnego" (art. 2 pkt 1 u.r.). Należy nadmienić, że pojęcie „dobro kultury” było podstawowym pojęciem używanym w nieobowiązującej już ustawie z dnia 15 lutego 1962 r. o ochronie dóbr kultury , której art. 2 stanowi, że „dobrem kultury w rozumieniu ustawy jest każdy przedmiot ruchomy lub nieruchomy, dawny lub współczesny, mający znaczenie dla dziedzictwa i rozwoju kulturalnego ze względu na jego wartość historyczną, naukową lub artystyczną". Pojęcie to straciło na znaczeniu w związku z wejściem w życie ustawy o ochronie zabytków, która jako podstawowego pojęcia używała terminu „zabytek”, rozumianego jako „nieruchomość lub rzecz ruchomą, ich części lub zespoły, będące dziełem człowieka lub związane z jego działalnością i stanowiące świadectwo minionej epoki bądź zdarzenia, których zachowanie leży w interesie społecznym ze względu na posiadaną wartość historyczną, artystyczną lub naukową" (art. 3 pkt 1 u.o.z.). Pewną zmianę w tym zakresie przyniosła ustawa z dnia 20 lutego 2015 r. o rzeczach znalezionych?,

7 O. Jakubowski, Karnoprawna ochrona zabytków ruchomych, w: K. Zeidler (red.), Raport dotyczący stanu ochrony prawnej oraz kierunków zmian w zakresie prawnej ochrony zabytków ruchomych w Polsce przygotowany w ramach realizacji Krajowego Programu Ochrony Zabytków i Opieki nad Zabytkami na lata 2014-2017 dla Narodowego Instytutu Muzealnictwa i Ochrony Zbiorów, Gdańsk 2016 [komputeropis], s. 330.

8 Ustawa z dnia 15 lutego 1962 r. o ochronie dóbr kultury, tekst jedn. Dz. U. z 1999 r. Nr 98, poz. 1150 ze zm.

9 Ustawa z dnia 20 lutego 2015 r. o rzeczach znalezionych, Dz. U. poz. 397. 
Nowe przestępstwa w systemie karnoprawnej ochrony dziedzictwa kultury... New crimes in the criminal law system regarding the protection of cultural heritage...

która do ustawy o ochronie zabytków dodała rozdział 2a („Krajowy rejestr utraconych dóbr kultury"), jednocześnie w art. 24a ust. 2 wskazując, że

Do krajowego rejestru utraconych dóbr kultury wpisuje się rzeczy ruchome będące:

1) zabytkami wpisanymi do rejestru,

2) muzealiami, o których mowa w art. 21 ust. 1 i 1a ustawy z dnia 21 listopada 1996 r. o muzeach (Dz. U. z 2012 r. poz. 987),

3) materiałami bibliotecznymi, o których mowa w art. 5 ustawy z dnia 27 czerwca 1997 r. o bibliotekach (Dz. U. z 2012 r. poz. 642 i 908 oraz z 2013 r. poz. 829), należącymi do narodowego zasobu bibliotecznego,

4) materiałami archiwalnymi, o których mowa w art. 1 ustawy z dnia 14 lipca 1983 r. o narodowym zasobie archiwalnym i archiwach (Dz. U. z 2011 r. Nr 123, poz. 698 i Nr 171, poz. 1016 oraz z 2014 r. poz. 822)

- utraconymi przez właściciela w wyniku popełnienia czynu zabronionego, określonego w art. 278 § $1 \mathrm{i} 3$, art. 279 § 1, art. 280-283 albo art. 284 § 1-3 ustawy z dnia 6 czerwca 1997 r. - Kodeks karny (Dz. U. Nr 88, poz. 553, z późn. zm.).

Można zatem powiedzieć, że pojęcie „dobro kultury” po wprowadzeniu wyżej wymienionych zmian „odżyło” 10 . Należy też zauważyć, że pojęcie „dobro kultury” po uchyleniu ustawy o ochronie dóbr kultury nie zniknęło z języka prawnego i było używane w Konstytucji Rzeczypospolitej Polskiej z dnia 2 kwietnia 1997 r. ${ }^{11}$ (art. 6 ust. 1, art. 73), ustawach (np. w ustawie z dnia 27 marca 2003 r. o planowaniu i zagospodarowaniu przestrzennym ${ }^{12}$, art. 2 pkt 10), rozporządzeniach (np. w rozporządzeniu Ministra Sprawiedliwości z dnia 7 kwietnia 2016 r. Regulamin wewnętrznego urzędowania powszechnych jednostek organizacyjnych prokuratury ${ }^{13}$, § 360 ust. 1 pkt 4). Pojęcie „dobro kultury” funkcjonuje również w ustawie z dnia 6 czerwca 1997 r. Kodeks karny ${ }^{14}$ (dalej: k.k.) - zob. art. 125 § 1 oraz art. 126 § 2 k.k. Pojęcie to używane jest też w piśmiennictwie, gdzie próbowano stworzyć definicje doktrynalne ${ }^{15}$.

Ustawa o restytucji definiuje także termin „zagraniczne narodowe dobro kultury” jako „sklasyfikowane lub zdefiniowane przez państwo członkowskie Unii Europejskiej inne niż Rzeczpospolita Polska, na podstawie ustawodawstwa tego państwa lub obowiązujących w nim procedur administracyjnych, jako narodowe

10 Por. rządowy projekt ustawy o restytucji narodowych dóbr kultury - uzasadnienie, druk nr 1371, s. 24. http://sejm.gov.pl/Sejm8.nsf/druk.xsp?nr=1371 [dostęp: 16.06.2017].

11 Konstytucja Rzeczypospolitej Polskiej z dnia 2 kwietnia 1997 r., Dz. U. Nr 78, poz. 483 ze zm.

12 Ustawa z dnia 27 marca 2003 r. o planowaniu i zagospodarowaniu przestrzennym, tekst jedn. Dz. U. z 2016 r., poz. 778 ze zm.

13 Rozporządzenie Ministra Sprawiedliwości z dnia 7 kwietnia 2016 r. Regulamin wewnętrznego urzędowania powszechnych jednostek organizacyjnych prokuratury, Dz. U. poz. 508 ze zm.

14 Ustawa z dnia 6 czerwca 1997 r. Kodeks karny, tekst jedn. Dz. U. z 2016 r., poz. 1137 ze zm.

15 Zob.np. B.J. Rouba, Terminologia i pojęcia podstawowe dla procesu ochrony dóbr kultury, w: T. Grzybkowska, J. Talbierska (red.), Dwór Artusa w Gdańsku. Sztuka i sztuka konserwacji. Materiały z konferencji naukowej, Gdańsk, Dwór Artusa 17-19 X 2002, Oficyna Pomorska, Warszawa 2004, s. 207. 


\section{ARTYKUŁY}

Bartłomiej Gadecki

dobro kultury o wartości artystycznej, historycznej lub archeologicznej w rozumieniu art. 36 Traktatu o funkcjonowaniu Unii Europejskiej" (art. 2 pkt 5). Przy czym przestępstwo z art. 52 ust. 1 u.r. dotyczy tylko utrudniania postępowania o zwrot „zagranicznego narodowego dobra kultury, o którym mowa w art. 18 ust. 1" u.r. Artykuł 18 ust. 1 u.r. wskazuje, że "Przepisy niniejszego rozdziału stosuje się do zwrotu zagranicznego narodowego dobra kultury wyprowadzonego z naruszeniem prawa z terytorium państwa Unii Europejskiej od dnia 1 stycznia 1993 r. i znajdującego się na terytorium Rzeczypospolitej Polskiej". Przy czym za wyprowadzenie z naruszeniem prawa z terytorium państwa Unii Europejskiej uznaje się wywóz zagranicznego narodowego dobra kultury, który nastąpił z naruszeniem przepisów tego państwa dotyczących ochrony zagranicznych narodowych dóbr kultury, określonych w art. 18 ust. 1, lub z naruszeniem rozporządzenia Rady (WE) nr 116/2009 z dnia 18 grudnia 2008 r. w sprawie wywozu dóbr kultury (art. 19 ust. 1 u.r.). Za wyprowadzenie $z$ naruszeniem prawa uważa się także naruszenie warunków czasowego wywozu zagranicznego narodowego dobra kultury, dokonanego zgodnie z przepisami, o których mowa w ust. 1, w szczególności naruszenie obowiązku przywozu zagranicznego narodowego dobra kultury z powrotem $w$ terminie (art. 19 ust. 2 u.r.).

Należy wskazać, że przestępstwo z art. 52 ust. 1 u.r. może być popełnione tylko z zamiarem bezpośrednim kierunkowym, sprawca bowiem ma działać „w celu ukrycia tego dobra".

Przestępstwo utrudniania postępowania o zwrot zagrożone jest karą pozbawienia wolności od 3 miesięcy do lat 5. Jednakże na zasadzie art. 37a k.k. można zamiast tej kary orzec grzywnę albo karę ograniczenia wolności, o której mowa w art. $34 \S 1$ a pkt 1 lub pkt 4 k.k. Wysokość ustawowego zagrożenia za czyn $z$ art. 52 ust. 1 u.r. umożliwia zastosowanie instytucji warunkowego umorzenia postępowania wobec sprawcy czynu (zob. art. 66 § 2 k.k.).

W art. 52 ust. 2 u.r. uregulowano wypadek mniejszej wagi. Jak zasadnie wskazano w orzecznictwie (co prawda wypowiadając się o przestępstwie rozboju, lecz pogląd ten można odpowiednio odnieść do innych przestępstw), o tym, czy rzeczywiście zachodzi wypadek mniejszej wagi, „decyduje ocena wszystkich znamion przedmiotowych i podmiotowych danego czynu, a ściślej ostateczny bilans z oceny znamion czynu. Wśród znamion strony przedmiotowej istotne znaczenie mają w szczególności: rodzaj dobra, w które godzi przestępstwo, zachowanie się i sposób działania sprawcy, użyte środki, charakter i rozmiar szkody wyrządzonej lub grożącej dobru prawnemu, czas miejsce i inne okoliczności popełnienia czynu oraz odczucie szkody przez pokrzywdzonego. Natomiast wśród elementów strony podmiotowej istotne są: stopień zawinienia oraz motywacja i cel działania sprawcy"16.

16 Wyrok Sądu Apelacyjnego w Katowicach z dnia 4 października 2007 r., II AKa 344/07, „Krakowskie Zeszyty Sądowe" 2008, nr 6, poz. 63, s. 41. 
Nowe przestępstwa w systemie karnoprawnej ochrony dziedzictwa kultury...

New crimes in the criminal law system regarding the protection of cultural heritage...

W art. 52 ust. 3 u.r. wprowadzono możliwości orzeczenia nawiązki, wskazując, że w razie skazania za przestępstwo określone w art. 52 ust. 1 u.r. sąd może orzec nawiązkę na wskazany cel społeczny związany z opieką nad zabytkami. Orzeczenie nawiązki jest fakultatywne („sąd może orzec”). Wysokość możliwej do orzeczenia nawiązki nie została określona w tym przepisie, należy zatem stosować przepisy części ogólnej Kodeksu karnego (zob. art. 116 k.k.). Zgodnie z art. 48 k.k., „nawiązkę orzeka się w wysokości do 100000 złotych, chyba że ustawa stanowi inaczej".

W art. 53 u.r. wskazano, że nie podlega karze m.in. osoba, która ujawniła wobec właściwego organu miejsce przechowywania dobra kultury lub osobę je przechowującą, na skutek czego dobro kultury zostało odnalezione, zatem nie wystarczy samo ujawnienie miejsca przechowywania dobra kultury lub osoby je przechowującej, ale konieczne jest, by dobro kultury zostało odnalezione. W przepisie nie wskazano terminu, do kiedy ma nastąpić zwrócenie dobra kultury lub ujawnienie miejsce przechowywania dobra kultury, wobec czego może to nastąpić aż do prawomocnego wyroku.

\section{Nowe przestępstwa w ustawie z dnia 21 listopada $1996 \mathrm{r}$. o muzeach oraz w ustawie z dnia 27 czerwca 1997 r. o bibliotekach}

W rozdziale 7 u.r., zatytułowanym „Zmiany w przepisach”, wprowadzono zmiany m.in.:

- ustawy z dnia 21 listopada 1996 r. o muzeach ${ }^{17}$ (dalej: ustawa o muzeach lub u.m.), dodając rozdział 5a („Przepis karny”), a w nim art. 34a o treści:

1. Kto bez pozwolenia wywozi za granicę muzealium, które nie stanowi zabytku w rozumieniu art. 3 pkt 1 ustawy z dnia 23 lipca 2003 r. o ochronie zabytków i opiece nad zabytkami, wpisane do inwentarza muzealiów w muzeum będącym instytucją kultury lub po wywiezieniu go za granicę nie sprowadza do kraju w okresie ważności pozwolenia, podlega karze pozbawienia wolności od 3 miesięcy do lat 5.

2. Jeżeli sprawca czynu określonego w ust. 1 działa nieumyślnie, podlega grzywnie, karze ograniczenia wolności albo pozbawienia wolności do lat 2.

3. W wypadku mniejszej wagi, sprawca podlega grzywnie, karze ograniczenia wolności albo pozbawienia wolności do roku.

4. W razie skazania za przestępstwo określone w ust. 1 sąd orzeka, a w razie skazania za przestępstwo określone w ust. 2 sąd może orzec, nawiązkę na wskazany cel społeczny związany z opieką nad zabytkami w wysokości od trzykrotnego do trzydziestokrotnego minimalnego wynagrodzenia przewidzianego $\mathrm{w}$ przepisach o minimalnym wynagrodzeniu za pracę;

17 Ustawa z dnia 21 listopada 1996 r. o muzeach, tekst jedn. Dz. U. z 2017 r., poz. 972. 


\section{ARTYKUŁY}

Bartłomiej Gadecki

- ustawy z dnia 27 czerwca 1997 r. o bibliotekach ${ }^{18}$ (dalej: ustawa o bibliotekach lub u.b.), dodając rozdział 11a („Przepis karny”), a w nim art. 29a w brzmieniu:

1. Kto bez pozwolenia wywozi za granicę materiał biblioteczny, który nie stanowi zabytku w rozumieniu art. 3 pkt 1 ustawy z dnia 23 lipca 2003 r. o ochronie zabytków i opiece nad zabytkami, znajdujący się w narodowym zasobie bibliotecznym lub po wywiezieniu go za granicę nie sprowadza do kraju w okresie ważności pozwolenia, podlega karze pozbawienia wolności od 3 miesięcy do lat 5.

2. Jeżeli sprawca czynu określonego w ust. 1 działa nieumyślnie, podlega grzywnie, karze ograniczenia wolności albo pozbawienia wolności do lat 2.

3. W wypadku mniejszej wagi, sprawca podlega grzywnie, karze ograniczenia wolności albo pozbawienia wolności do roku.

4. W razie skazania za przestępstwo określone w ust. 1 sąd orzeka, a w razie skazania za przestępstwo określone w ust. 2 sąd może orzec, nawiązkę na wskazany cel społeczny związany z opieką nad zabytkami w wysokości od trzykrotnego do trzydziestokrotnego minimalnego wynagrodzenia za pracę określonego na podstawie przepisów ustawy z dnia 10 października 2002 r. o minimalnym wynagrodzeniu za pracę (Dz. U. z 2017 r. poz. 847).

W ustawie o muzeach oraz w ustawie o bibliotekach uregulowano przestępstwo nielegalnego wywozu za granicę, odpowiednio muzealium i materiału bibliotecznego niestanowiących zabytku w rozumieniu art. 3 pkt 1 u.o.z. Uregulowano odpowiedzialność za typ umyślny (art. 34a ust. 1 u.m. oraz art. 29a ust. 1 u.b.) oraz nieumyślny (art. 34a ust. 2 u.m. oraz art. 29a ust. 2 u.b.). Wprowadzono również odpowiedzialność za wypadek mniejszej wagi (art. 34a ust. 3 u.m. oraz art. 29a ust. 3 u.b.), przy czym z treści przepisu oraz jego umiejscowienia można wnioskować, że wypadek mniejszej wagi dotyczy zarówno typu umyślnego, jak i nieumyślnego. Wprowadzono też obowiązek orzeczenia w razie skazania za przestępstwo w typie umyślnym nawiązki na wskazany cel społeczny związany z opieką nad zabytkami oraz fakultatywnie („sąd może orzec”) w przypadku skazania za typ nieumyślny (art. 34a ust. 4 u.m. oraz art. 29a ust. 4 u.b.). Co jest interesujące, odmiennie ujęto sposób określenia wysokości nawiązki, w ustawie o muzeach wskazując, że nawiązkę orzeka się „w wysokości od trzykrotnego do trzydziestokrotnego minimalnego wynagrodzenia przewidzianego w przepisach o minimalnym wynagrodzeniu za pracę", a w ustawie o bibliotekach, że nawiązkę orzeka się „w wysokości od trzykrotnego do trzydziestokrotnego minimalnego wynagrodzenia za pracę określonego na podstawie przepisów ustawy z dnia 10 października 2002 r. o minimalnym wynagrodzeniu za pracę (Dz. U. z 2017 r. poz. 847)". Wobec takiego brzmienia przepisów można mieć wątpliwość, czy w obu przypadkach podstawa do określenia wysokości nawiązki ma być taka sama i czy kwota minimalnego wynagrodzenia potrzebna do ustalania wysokości nawiązki jest ustalana na podstawie

18 Ustawa z dnia 27 czerwca 1997 r. o bibliotekach, tekst jedn. Dz. U. z 2012 r., poz. 642 ze zm. 
Nowe przestępstwa w systemie karnoprawnej ochrony dziedzictwa kultury...

New crimes in the criminal law system regarding the protection of cultural heritage...

art. 2 ustawy z dnia 10 października 2002 r. o minimalnym wynagrodzeniu za pracę $e^{19}$ (dalej: u.m.w.), czy wynika z art. 25 u.m.w. Należy zaznaczyć, że w ustawie o minimalnym wynagrodzeniu za pracę określono tryb ustalania wysokości minimalnego wynagrodzenia za pracę. Jak podano w art. 2 ust. 1 u.m.w., „Wysokość minimalnego wynagrodzenia za pracę, zwanego dalej «minimalnym wynagrodzeniem», jest corocznie przedmiotem negocjacji w ramach Rady Dialogu Społecznego". Przy czym jeżeli Rada Dialogu Społecznego nie uzgodni w terminie, o którym mowa w art. 2 ust. 3 u.m.w., wysokości minimalnego wynagrodzenia w roku następnym oraz nie ustali wysokości minimalnej stawki godzinowej w roku następnym, Rada Ministrów ustala, w drodze rozporządzenia, w terminie do dnia 15 września każdego roku, wysokość minimalnego wynagrodzenia w roku następnym, a także wysokość minimalnej stawki godzinowej w roku następnym wraz z terminem zmiany tych wysokości (zob. art. 2 ust. 5 u.m.w.). Trzeba podkreślić, że nie byłoby żadnych wątpliwości przy określaniu kwoty potrzebnej do ustalania wysokości nawiązki, gdyby nie art. 25 u.m.w. o treści:

Ilekroć w przepisach prawa jest mowa o „najniższym wynagrodzeniu za pracę pracowników" przez odwołanie się do odrębnych przepisów lub do Kodeksu pracy albo przez wskazanie Ministra Pracy i Polityki Socjalnej, Ministra Pracy i Polityki Społecznej lub ministra właściwego do spraw pracy jako zobowiązanego do ustalania takiego wynagrodzenia na podstawie odrębnych przepisów lub Kodeksu pracy, oznacza to kwotę 760 zł.

Na marginesie należy podać, że w przestępstwie nielegalnego wywozu zabytku uregulowanego w art. 109 u.o.z. w ust. 3 wskazano, że nawiązkę orzeka się „W wysokości od trzykrotnego do trzydziestokrotnego minimalnego wynagrodzenia".

W doktrynie, co do art. 109 ust. 3 u.o.z., przyjmuje się, że kwota minimalnego wynagrodzenia potrzebna do ustalania wysokości nawiązki jest ustalana na podstawie art. 2 u.m.w. ${ }^{20} \mathrm{~W}$ ustawie o muzeach odwołano się do „minimalnego wynagrodzenia przewidzianego w przepisach o minimalnym wynagrodzeniu za pracę”, a w ustawie o bibliotekach do „minimalnego wynagrodzenia za pracę określonego na podstawie przepisów ustawy z dnia 10 października 2002 r. o minimalnym wynagrodzeniu za pracę (Dz. U. z 2017 r. poz. 847)", a nie - jak tego wymaga art. 25 u.m.w. - do „najniższego wynagrodzenia za pracę pracowników”, zatem, kierując się wykładnią językową, można uznać, że kwota minimalnego wynagrodzenia potrzebna do ustalania wysokości nawiązki nie jest „kwotą sztywną”, wynikającą z brzmienia art. 25 u.m.w., lecz jest ustalana na podstawie art. 2 u.m.w. Dotyczy

19 Ustawa z dnia 10 października 2002 r. o minimalnym wynagrodzeniu za pracę, tekst jedn. Dz. U. z 2017 r. poz. 847.

20 Zob. B. Gadecki, Możliwość orzekania przepadku oraz nawiqzki wobec sprawców przestępstw oraz wykroczeń zawartych w ustawie z dnia 23 lipca 2003 roku o ochronie zabytków i opiece nad zabytkami, „Santander Art and Culture Law Review" 2016, nr 1(2), s. 100-101. 


\section{ARTYKUŁY}

Bartłomiej Gadecki

to kwoty potrzebnej do ustalania wysokości nawiązki w ustawie o muzeach oraz w ustawie o bibliotekach, mimo innego brzmienia przepisów.

Zgodnie z rozporządzeniem Rady Ministrów z dnia 9 września 2016 r. w sprawie wysokości minimalnego wynagrodzenia za pracę w 2017 r. ${ }^{21}$, wydanym na podstawie art. 2 ust. 5 u.m.w., od dnia 1 stycznia 2017 r. minimalne wynagrodzenie za pracę wynosi 2000 zł. Zatem nawiązkę, zarówno w ustawie o muzeach, jak i w ustawie o bibliotekach, można orzec w wysokości od 6000 zł do 60000 zł.

\section{Podsumowanie}

Wprowadzenie nowych przestępstw niewątpliwie wzmocniło system karnoprawnej ochrony dziedzictwa kultury. Wprowadzone dwa przestępstwa związane z nielegalnym wywozem wkomponowują się w system karnoprawnej ochrony dziedzictwa przed nielegalnym wywozem z kraju. Należy wskazać, że nielegalny wywóz zabytków jest penalizowany w art. 109 u.o.z., który przewiduje za typ umyślny sankcję w postaci kary pozbawienia wolności od 3 miesięcy do lat 5 (art. 109 ust. 1 u.o.z.), a za typ nieumyślny - grzywnę, karę ograniczenia wolności albo pozbawienia wolności do lat 2 (art. 109 ust. 2 u.o.z.). Zatem wysokość sankcji przewidzianych $\mathrm{w}$ nowych przepisach karnych zawartych $\mathrm{w}$ ustawie o muzeach (art. 34a ust. 1 i 2) oraz w ustawie o bibliotekach (art. 29a ust. 1 i 2) jest spójna z ustawą o ochronie zabytków, bowiem za typ umyślny przewidziano $w$ nich sankcję $w$ postaci kary pozbawienia wolności od 3 miesięcy do lat 5 (art. 34a ust. 1 u.m. oraz art. 29a ust. 1 u.b.), a za typ nieumyślny - grzywnę, karę ograniczenia wolności albo pozbawienia wolności do lat 2 (art. 34a ust. 2 u.m. oraz art. 29a ust. 2 u.b.). Nowością w ustawie o muzeach i ustawie o bibliotekach, w porównaniu z przepisem z ustawy o ochronie zabytków, jest wprowadzenie wypadku mniejszej wagi. Należy także wskazać, że w skład systemu karnoprawnej ochrony dziedzictwa kulturowego przed wywozem wchodzi również art. 53 ustawy z dnia 14 lipca $1983 \mathrm{r}$. o narodowym zasobie archiwalnym i archiwach ${ }^{22}$ (dalej: u.n.z.a.) regulujący odpowiedzialność za nielegalny wywóz materiałów archiwalnych, przy czym typ umyślny zagrożony jest karą pozbawienia wolności do lat 3 (art. 53 ust. 1 u.n.z.a.), a typ nieumyślny - grzywną albo karą ograniczenia wolności (art. 53 ust. 2 u.n.z.a.). Zatem w celu ujednolicenia sankcji za nielegalny wy wóz elementów wchodzących w skład dziedzictwa kulturowego konieczne jest podwyższenie sankcji za nielegalny wywóz materiałów archiwalnych.

21 Rozporządzenie Rady Ministrów z dnia 9 września 2016 r. w sprawie wysokości minimalnego wynagrodzenia za pracę w 2017 r., Dz. U. z 2016 r. poz. 1456.

22 Ustawa z dnia 14 lipca 1983 r. o narodowym zasobie archiwalnym i archiwach, tekst jedn. Dz. U. z 2016 r. poz. 1506 ze zm. 
Nowe przestępstwa w systemie karnoprawnej ochrony dziedzictwa kultury... New crimes in the criminal law system regarding the protection of cultural heritage...

Trzeba także wskazać, że w przepisach dotyczących nielegalnego wywozu „składników” tworzących dziedzictwo kultury mamy do czynienia z trzema sposobami ujęcia w przepisie wysokości możliwej do orzeczenia nawiązki. O ile wykładnia przepisów ustawy o ochronie zabytków, ustawy o muzeach oraz ustawy o bibliotekach wskazuje, że kwota potrzebna do ustalania wysokości nawiązki określana jest na podstawie art. 2 u.m.w., to ujęcie w treści przepisów trzech różnych sformułowań, w których następuje odwoływanie się do „minimalnego wynagrodzenia” (u.o.z.), „minimalnego wynagrodzenia przewidzianego w przepisach o minimalnym wynagrodzeniu za pracę” (ustawa o muzeach), „minimalnego wynagrodzenia za pracę określonego na podstawie przepisów ustawy z dnia 10 października 2002 r. o minimalnym wynagrodzeniu za pracę (Dz. U. z 2017 r. poz. 847)" (ustawa o bibliotekach), należy ocenić krytycznie, bowiem zasadniczo nie można dwóch terminów uznawać za synonimy ${ }^{23}$. Od ustawodawcy powinno wymagać się konsekwencji w używaniu określonych terminów ${ }^{24}$.

\section{Bibliografia}

Gadecki B., Możliwość orzekania przepadku oraz nawiq̨zki wobec sprawców przestępstw oraz wykroczeń zawartych w ustawie z dnia 23 lipca 2003 roku o ochronie zabytków i opiece nad zabytkami, „Santander Art and Culture Law Review” 2016, nr 1(2).

Jakubowski O., Karnoprawna ochrona zabytków ruchomych, w: K. Zeidler (red.), Raport dotyczący stanu ochrony prawnej oraz kierunków zmian w zakresie prawnej ochrony zabytków ruchomych w Polsce przygotowany w ramach realizacji Krajowego Programu Ochrony Zabytków i Opieki nad Zabytkami na lata 2014-2017 dla Narodowego Instytutu Muzealnictwa i Ochrony Zbiorów, Gdańsk 2016 [komputeropis].

Konstytucja Rzeczypospolitej Polskiej z dnia 2 kwietnia 1997 r., Dz. U. Nr 78, poz. 483 ze zm.

Morawski L., Zasady wykładni prawa, TNOIK, Toruń 2010.

Radecki W., w: System prawa karnego, t. 11: M. Bojarski (red.), Szczególne dziedziny prawa karnego. Prawo karne wojskowe, skarbowe i pozakodeksowe, C.H. Beck, Instytut Nauk Prawnych PAN, Warszawa 2014,

Rouba B.J., Terminologia i pojęcia podstawowe dla procesu ochrony dóbr kultury, w: T. Grzybkowska, J. Talbierska (red.), Dwór Artusa w Gdańsku. Sztuka i sztuka konserwacji. Materiały z konferencji naukowej, Gdańsk, Dwór Artusa 17-19 X 2002, Oficyna Pomorska, Warszawa 2004.

Rozporządzenie Ministra Sprawiedliwości z dnia 7 kwietnia 2016 r. Regulamin wewnętrznego urzędowania powszechnych jednostek organizacyjnych prokuratury, Dz. U. poz. 508 ze zm.

Rozporządzenie Rady Ministrów z dnia 9 września 2016 r. w sprawie wysokości minimalnego wynagrodzenia za pracę w 2017 r., Dz. U. z 2016 r. poz. 1456.

Rządowy projekt ustawy o restytucji narodowych dóbr kultury - uzasadnienie, druk nr 1371, s. 24. http://sejm.gov.pl/Sejm8.nsf/druk.xsp?nr=1371 [dostęp: 16.06.2017].

23 Zob. L. Morawski, Zasady wykładni prawa, TNOIK, Toruń 2010, s. 117-119.

24 Zob. J. Wróblewski, Zasady tworzenia prawa, PWN, Warszawa 1989, s. 139-140. 


\section{ARTYKUŁY}

Bartłomiej Gadecki

Ustawa z dnia 15 lutego 1962 r. o ochronie dóbr kultury, tekst jedn. Dz. U. z 1999 r. Nr 98, poz. 1150 ze zm.

Ustawa z dnia 14 lipca 1983 r. o narodowym zasobie archiwalnym i archiwach, tekst jedn. Dz. U. z 2016 r., poz. 1506 ze zm.

Ustawa z dnia 21 listopada 1996 r. o muzeach, tekst jedn. Dz. U. z 2017 r., poz. 972.

Ustawa z dnia 6 czerwca 1997 r. Kodeks karny, tekst jedn. Dz. U. z 2016 r., poz. 1137 ze zm.

Ustawa z dnia 27 czerwca 1997 r. o bibliotekach, tekst jedn. Dz. U. z 2012 r., poz. 642 ze zm.

Ustawa z dnia 10 października 2002 r. o minimalnym wynagrodzeniu za pracę, tekst jedn. Dz. U. z 2017 r. poz. 847.

Ustawa z dnia 27 marca 2003 r. o planowaniu i zagospodarowaniu przestrzennym, tekst jedn. Dz. U. z 2016 r., poz. 778 ze zm.

Ustawa z dnia 23 lipca 2003 r. o ochronie zabytków i opiece nad zabytkami, tekst jedn. Dz. U. z 2014 r., poz. 1446 ze zm.

Ustawa z dnia 20 lutego 2015 r. o rzeczach znalezionych, Dz. U. poz. 397.

Ustawa z dnia 25 maja 2017 r. o restytucji narodowych dóbr kultury, Dz. U. poz. 1086.

Wróblewski J., Zasady tworzenia prawa, PWN, Warszawa 1989.

Wyrok Sądu Apelacyjnego w Katowicach z dnia 4 października 2007 r., II AKa 344/07, „Krakowskie Zeszyty Sądowe" 2008, nr 6, poz. 63.

Zeidler K., Prawo ochrony dziedzictwa kultury, Wolters Kluwer Polska, Warszawa 2007. 